\title{
STUDI ANALISIS PEMBENTUKAN KARAKTER ISLAMI PESERTA DIDIK DI PONDOK PESANTRENMODERN DAARUL MUTTAQIEN II PASAR KEMIS KABUPATEN TANGERANG
}

\author{
Philia Almas Santika, Nur Halimah \\ Universitas Islam Syekh Yusuf Tangerang \\ 1703020038@students.unis.ac.id
}

Naskah diterima: 25 Oktober 2021, direvisi: 30 Oktober 2021, disetujui: 10 Desember 2021

\section{Abstrak}

Penelitian ini dilakukan dengan tujuan untuk mengetahui upaya yang dilakukan dalam pembentukan karakter islami pada peserta didik di Pondok Pesantren Modern Daarul Muttaqien Il Pasar Kemis Kabupaten Tangerang. Jenis penelitian ini adalah penelitian kualitatif atau deskriptif kualitatif dan menggunakan pendekatan kualitatif. Informan dalam penelitian ini adalah pengurus pondok pesantren dan santri Pondok Pesantren Modern Daarul Muttaqien II Pasar Kemis. Metode pengumpulan data dalam penelitian ini berupa wawancara, observasi dan dokumentasi. Teknik yang digunakan dalam menganalisis data adalah analisis kualitatif. Dari hasil penelitian ini, diperoleh kesimpulan bahwa upaya yang dilakukan pesantren dalam pembentukan karakter islami pada peserta didik yaitu dengan mengintegrasikan nilai-nilai karakter islami pada semua mata pelajaran (intrakulikuler) juga mengintegrasikan nilai-nilai karakter islami diluar kelas (ekstrakulikuler) dengan cara keteladanan, pembiasaan, pemberian teguran dan nasihat serta pemberian hadiah dan hukuman.

Kata Kunci: Pembentukan, Karakter, Pesantren 


\section{PENDAHULUAN}

$$
\text { Ki Hajar Dewantara }
$$
mengungkapkan pandangannya terkait pendidikan, menurutnya pendidikan adalah upaya yang sengaja dilakukan dalam menuntun segala potensi yang dimiliki pada anak agar mereka sebagai manusia dan sebagai masyarakat dapat mencapai keselamatan dan kebahagiaan yang setinggi-tingginya.'

$$
\text { Pandangan lainnya tentang }
$$
pendidikan sebagaimana yang dikatakan oleh Ade Holisoh, Karmawan dan Nur Halimah, bahwa pendidikan merupakan upaya sadar untuk mengembangkan potensi yang dianugerahkan Tuhan kepada manusia dan diarahkan pada tujuan yang diharapkan, agar memanusiakan manusia atau menjadikannya insan kamil, manusia utuh atau kaffah. ${ }^{2}$

Dari pandangan di atas, jelas bahwa pendidikan sebagai upaya dalam mengembangkan dan memajukan potensi (budi pekerti, pikiran dan jasmani) yang dimiliki setiap peserta didik agar dapat memajukan

\footnotetext{
'Mohammad Fahmi Nugraha, et.al., Pengantar Pendidikan dan Pembelajaran di Sekolah Dasar, (Tasikmalaya: Edu Publisher, 2020), cet. ke-l, h. 6

${ }^{2}$ Ade Holisoh, Karmawan, dan Nur Halimah, Kedisiplinan Siswa Dan Motivasi Belajar Dalam Meningkatkan Prestasi Belajar Siswa Pada Pelajaran Akuntansi Di Madrasah Aliyah Negeri Kabupaten Tangerang, 14.1 (2020), 80.
}

kesempurnaan hidup, yaitu hidup dan menghidupkan peserta didik yang selaras dengan alam dan masyarakat juga dapat meraih kebahagiaan di akhirat. Hal tersebut dapat dipahami bahwa pendidikan tidak hanya berorientasi kepada domain kognitif saja, tetapi domain afektif dan psikomotor.

Dengan adanya pengertian di atas jelas bahwa salah satu tujuan dari proses pendidikan di sekolah atau lembaga pendidikan lainnya, ialah adanya pembentukan karakter. Pembentukan karakter di sekolah menjadi sangat penting dan semakin mendesak untuk dilakukan mengingat berbagai macam perilaku yang nonedukatif kini telah memasuki dunia pendidikan.

Oleh karena itu, upaya mencerdaskan peserta didik yang menekankan pada aspek intelektual perlu diimbangi dengan pembentukan karakter yang termasuk dalam materi yang harus diajarkan, dikuasai dan di praktekkan oleh peserta didik dalam kehidupan sehari-hari. Sebab karakter merupakan nilai-nilai perilaku manusia yang berhubungan dengan Tuhan Yang Maha Esa, diri sendiri, sesama manusia, lingkungan dan kebangsaan yang terwujud dalam pikiran, sikap, perasaan, 
perkataan, dan perbuatan berdasarkan norma-norma agama, hukum, tata krama, budaya dan adat istiadat. ${ }^{3}$

Terkait pentingnya bimbingan, arahan dan strategi dalam membentuk karakter manusia, pesantren sebagai salah satu jenis lembaga pendidikan Islam di Indonesia telah terbukti secara empiris mampu mengembangkan peserta didik dari berbagai aspek, meliputi kemampuan intelektual, emosional dan pembentukan karakter religius, sehingga lahirlah output pesantren yang memiliki pengetahuan dan akhlak karimah atau berkarakter. ${ }^{4}$

Hal ini sesuai dengan tujuan umum dari pondok pesantren yaitu membina warga negara agar memiliki kepribadian muslim sesuai dengan ajaran-ajaran agama Islam dan menanamkan rasa keagamaan tersebut pada semua kehidupannya serta menjadikannya sebagai orang yang berguna bagi agama, masyarakat dan negara. ${ }^{5}$ Alasan tersebut didasari karena pesantren memiliki lingkungan strategis dan kondusif yang mempermudah

3 Ahmad Mufid Anwari, Potret Pendidikan Karakter di Pesantren: Aplikasi Model Keteladanan dan Pembiasaan dalam Ruang Publik, (Tasikmalaya: Edu Publisher, 2020), h. 12

4 Fifi Nofiaturrahmah, 'Metode Pendidikan Karakter di Pesantren', Jurnal Pendidikan Agama Islam, 11.2 (2017), 201-16.

5 Halid Hanafi, et.al., Ilmu Pendidikan Islam, (Yogyakarta: Deepublish, 2019), cet. ke-2, h. 402 potensi peserta didik dapat tumbuh dan berkembang secara optimal dalam menanamkan niai-nilai Islam dalam proses pembentukan karakter islami.

Pembentukan karakter islami merupakan upaya yang dilakukan secara sistematis dan terencana agar seseorang dapat mengenal, peduli dan menanamkan nilai-nilai Islam sehingga terbentuk manusia sempurna baik dari sisi intelektual, spiritual, akhlak dan keterampilan. $^{6}$

Berdasarkan uraian di atas, penulis tertarik untuk melakukan penelitian terkait dengan pembentukan karakter islami peserta didik di Pesantren. Penulis memilih lokasi di Pondok Pesantern Modern Daarul Muttaqien II Pasar Kemis Kabupaten Tangerang, dikarenakan pesantren merupakan lembaga pendidikan berbasis Islam yang identik dengan nilai-nilai Islam yang ditanamkan pada peserta didik dan memiliki peluang besar untuk melahirkan generasi muslim yang memiliki kemampuan dari berbagai aspek.

Namun setelah penulis melakukan survey di Pondok Pesantren Modern Daarul Muttaqien Il Pasar Kemis Kabupaten Tangerang, saat kegiatan

\footnotetext{
${ }^{6}$ Yuliharti, 'Pembentukan Karakter Islami dalam Hadis dan Implikasinya pada Jalur Pendidikan Non Formal', Potensia: Jurnal Kependidikan Islam, 4.2 (2019).
} 
belajar mengajar berlangsung penulis menemukan ada beberapa dari peserta didik yang belum mengamalkan karakter islami seperti yang diharapkan. Masih adanya peserta didik yang kurang peduli terhadap lingkungan sekitarnya dengan membuang sampah sembarangan, tidak disiplin waktu saat proses kegiatan belajar berlangsung dan ada dari beberapa peserta didik yang kurang hormat kepada guru.

Dilihat dari sistem dan lokasi yang seharusnya memiliki peluang besar dalam menanamkan nilai-nilai Islam dan membentuk karakter islami, seharusnya sudah tidak ada lagi peserta didik yang melakukan penyimpangan sosial seperti yang dijelaskan. Dengan berbagai permasalahan yang disebutkan tadi, penulis tertarik untuk melakukan penelitian dengan judul "STUDI ANALISIS PEMBENTUKAN KARAKTER ISLAMI PESERTA DIDIK DI PONDOK PESANTREN MODERN DAARUL MUTTAQIEN II PASAR KEMIS KABUPATEN TANGERANG".

Tujuan dari penelitian ini adalah untuk mengetahui upaya pesantren dalam membentuk karakter islami pada peserta didik di Pondok Pesantren Modern Daarul Muttaqien 11 Pasar Kemis Kabupaten Tangerang.

\section{METODE PENELITIAN}

Penelitian ini merupakan jenis penelitian lapangan (field research) dengan menggunakan pendekatan kualitatif dengan analisis data deskriptif. Penelitian kualitatif deskriptif dalam prosedur penelitian yang menghasilkan data berupa kata-kata tertulis yang merupakan deskripsi tentang suatu masalah. Sumber data yang digunakan pada penelitian ini adalah sumber primer dan sumber sekunder. Metode yang digunakan dalam pengumpulan data dalam penelitian ini yaitu melalui wawancara, observasi, dan dokumentasi.

\section{PEMBAHASAN DAN HASIL}

\section{PENELITIAN}

Kata "Pembentukan" dalam Kamus Bahasa Indonesia (KBI) yaitu proses, cara, perbuatan membentuk. ${ }^{7}$ Sedangkan secara istilah pembentukan memiliki makna usaha luar yang dilakukan kepada tujuan tertentu guna membimbing faktor-faktor pembawa hingga terwujud dalam suatu aktivitas rohani atau jasmani.

Kata "Karakter" dalam Kamus Bahasa Indonesia adalah tabiat, sifatsifat kejiwaan, akhlak atau budi pekerti yang membedakan seseorang dengan

7 Pusat Bahasa Departemen Pendidikan Nasional, Kamus Bahasa Indonesia, (Jakarta: Pusat Bahasa, 2008), h. 180 
yang lain dan watak. ${ }^{8}$ Dalam terminologi lslam, karakter disamakan dengan khuluq (bentuk tunggal dari akhlaq), akhlak yaitu kondisi batiniyah dan lahiriyah manusia. ${ }^{9}$

Sedangkan karakter menurut Thomas lickona yaitu mengetahui kebaikan, menginginkan kebaikan, dan melakukan segala sesuatu yang baik. ${ }^{10}$

Sedangkan kata "Islami" dalam Kamus Besar Bahasa Indonesia memiliki arti bersifat keislaman." Jadi, pembentukan karakter islami adalah proses membentuk agar terciptanya sifat, budi pekerti, akhlak, etika atau tingkah laku yang bersifat keislaman pada diri seseorang. Pembentukan karakter islami juga dapat dipahami sebagai upaya penanaman kecerdasan kepada peserta didik dalam berpikir, bersikap dan berperilaku sesuai dengan nilai-nilai luhur yang menjadi jati dirinya, diwujudkan dalam interaksi dengan Tuhannya, diri sendiri, antar sesama dan lingkungannya.

Karakter islami dalam Islam tersimpul dalam karakter pribadi Rasulullah SAW. Dalam pribadi Rasul

8 Pusat Bahasa Departemen Pendidikan Nasional, Kamus Bahasa ... h. 639

9 Ramayulis, Ilmu Pendidikan Islam, Jakarta: Kalam Mulia, 2008, h. 65

10 Muhammad Yaumi, Pendidikan Karakter: Landasan, Pilar, dan Implementasi, (Jakarta: Kencana, 2016), cet. ke-2, h. 7

"https://kbbi.kemdikbud.go.id/entri/islami, diakses pada hari Senin tanggal 14 Juni 2021 pukul 13:35 WIB bersemai nilai-nilai akhlak yang mulia dan agung. Oleh karena itu, Rasulullah adalah suri tauladan yang baik yang patut kita teladani. Karakter atau akhlak islami dapat dikatakan sebagai akhlak yang bersumber pada ajaran Allah dan Rasul-Nya.(Wahyuningtiyas, 2019)

Dalam hal ini, standar atau ukuran baik dan buruknya karakter seseorang dalam Islam adalah berdasarkan $\mathrm{Al}-$ Qur'an dan Sunnah Nabi, sebab keduanya merupakan pedoman hidup bagi manusia khususnya seorang muslim yang bersifat permanen tetapi fleksibel. Di antara ayat Al-Qur'an yang menjadi dasar pendidikan karakter sebagaimana yang ada dalam surat Lukman ayat 17-18 adalah:

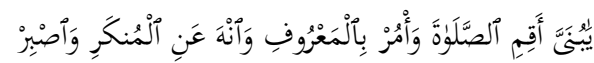

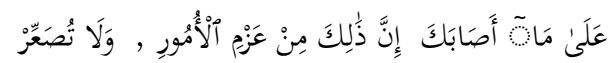

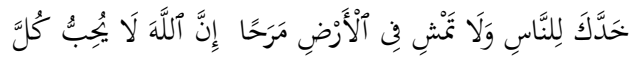

$$
\begin{aligned}
& \text { مُخْنَالِ فَخُوِرِ }
\end{aligned}
$$


berjalan di bumi dengan angkuh. Sungguh, Allah tidak menyukai orangorang yang sombong dan membanggakan diri".

Sebagaimana visi pesantren yang tertulis yaitu "Menjadi sekolah yang unggul dalam bidang llmu Pengetahuan dan Terknologi (IPTEK) dan dalam bidang Iman dan Taqwa (IMTAQ), serta menjunjung tinggi nilai-nilai akhlaqul karimah", maka kedudukan pendidikan karakter di Pesantren Modern Daarul Muttaqien $\mathrm{Il}$ ini menjadi perhatian yang sangat penting dalam membentuk karakter islami pada peserta didik.

Berdasarkan hasil wawancara yang telah dilakukan penulis dengan beberapa narasumber dan observasi yang dilakukan, dapat diketahui bahwa upaya yang dilakukan pesantren dalam proses pembentukan karakter islami pada peserta didik kurang lebih sesuai dengan teori yang dikemukakan oleh Marzuki dalam bukunya "Pendidikan Karakter Islam".'2 Adapun upaya yang dilakukan pesantren dalam pembentukan karakter islami pada peserta didik di Pondok Pesantren Modern Daarul Muttaqien II yaitu:

${ }^{12}$ Marzuki, Pendidikan Karakter Islam, (Jakarta: Bumi Medika, 2015), cet. ke-1, h. 112-113 a. Integrasi nilai-nilai karakter islami saat proses kegiatan belajar mengajar berlangsung

Pengintegrasian nilai-nilai karakter islami saat kegiatan belajar mengajar berlangsung dan terintegrasi ke dalam semua mata pelajaran, tujuannya agar peserta didik dapat mengetahui dan memahami apa saja dan tujuan dari pembentukan karakter islami tersebut. Diketahui bahwa saat proses Kegiatan Belajar Mengajar (KBM) secara tidak langsung, pesantren membentuk peserta didik yang mengajarkan peserta didik untuk bisa memanajemen waktu dengan sebaik mungkin. Tujuannya adalah agar peserta didik terbiasa untuk disiplin di kehidupan sehari-harinya. Dengan adanya peraturan peserta didik untuk menggunakan pakaian serapih mungkin, hal tersebut bertujuan agar peserta didik dapat membiasakan dirinya untuk berpenampilan sopan dan rapih.

Integrasi nilai-nilai karakter islami yang dilakukan guru saat proses KBM berlangsung ini dimulai dengan beberapa tahap, di antaranya dengan tahap perencanaan, pelaksanaan hingga evaluasi pembelajaran.

Pengintegrasian pendidikan karakter melalui proses pembelajaran semua mata pelajaran di sekolah sekarang menjadi salah satu model yang diterapkan di banyak sekolah. Model ini 
ditempuh dengan paradigma bahwa semua guru adalah pendidik karakter. Semua mata pelajaran juga diasumsikan memiliki misi dalam membentuk karakter islami pada peserta didik.

\section{b. Pembiasaan}

Pembiasaan adalah sesuatu yang dilakukan secara berulang-ulang agar sesuatu itu dapat menjadi kebiasaan. Pada pelaksanaannya, peserta didik dipaksa untuk melakukan kegiatankegiatan terpuji agar kedepannya mereka menjadi terbiasa untuk melakukan hal-hal baik tanpa diperintah oleh siapapun. Karena pembiasaannya sebenarnya berintikan pengalaman, yang dibiasakan itu adalah sesuatu yang istimewa, yang dapat menghemat kekuatan, karena akan menjadi kebiasaan yang melekat dan spontan.

Terkait pembiasaan yang dilakukan dalam proses pembentukan karakter islami pada peserta didik bahwa pembiasaan yang dilakukan di pesantren tentunya merupakan segala bentuk kegiatan dan perbuatan yang mencerminkan nilai-nilai Islam yang bersifat ibadah. Kegiatan pembiasaan yang dilakukan peserta didik untuk memperlancar proses pembentukan karakter islami dapat dilakukan saat kegiatan belajar mengajar berlangsung dan diluar jam tersebut.
Saat proses kegiatan belajar berlangsung, peserta didik dibiasakan untuk menjaga kerapihan pakaiannya, dan dibiasakan untuk disiplin waktu. Guru juga membiasakan peserta didik untuk memulai dan menyudahi kegiatan belajar mengajar dengan membaca do'a. Sedangkan pembiasaan yang dilakukan di luar kegiatan belajar mengajar yaitu:

1. Shalat berjama'ah

Sebagaimana di pesantren lainnya, di Pesantren Daarul Muttaqien 11 ini pun melaksanakan shalat lima waktu maupun shalat tahajjud secara berjama'ah setiap harinya. Hal ini bertujuan agar peserta didik terbiasa untuk beribadah secara berjama'ah. Shalat berjama'ah ini berlangsung di masing-masing masjid putra maupun putri dengan imamnya ustaz/ustazah dan pengurus yang ada di lingkungan pesantren.

2. Membaca Al-Qur'an

Sebelum atau setelah shalat berjama'ah peserta didik dibiasakan untuk membaca Al-Qur'an secara bersama-sama. Setiap hari sebelum melaksanakan shalat maghrib berjama'ah, dilangsungkan taddarus Al-Quran yakni dengan membaca surat Ar-Rahman dan Al-Waqiah. Setelah shalat maghrib berjama'ah, peserta didik berpencar untuk 
mengaji Al-Qur'an dengan secara berkelompok. Lalu dibiasakan pula setiap malam Jum'at melangsungkan kegiatan tahlil. Setiap malam Senin setelah berjama'ah shalat maghrib, peserta didik juga dibiasakan untuk berzanji secara bersama-sama yang dipimpin oleh ustaz/ustazah dan pengurus.

3. Belajar malam

Agar terciptanya peserta didik yang disiplin waktu dan cinta ilmu, di pesantren ini dibiasakan peserta didik untuk melangsungkan kegiatan belajar mengajar bersama di kelasnya masing-masing. Kegiatan belajar malam ini bertujuan agar peserta didik dapat mempersiapkan materi belajar esok hari. Pelaksanaan belajar mala mini berlangsung setiap malam Senin sampai malam Sabtu dimulai setelah shalat isya berjamaah dan pembagian kosa kata sampai pukul 21:45 WIB. Kegiatan ini pun dan dibimbing oleh wali kelasnya masing masing dan diawasi oleh pengurus organisasi santri.

4. Berbicara bahasa Inggris dan bahasa Arab

Agar peserta didik memiliki kemampuan di bidang bahasa, maka percakapan yang berlangsung di pesantren ini diwajibkan menggunakan bahasa Arab atau bahasa lnggris sebagai bahasa resmi pesantren. Untuk menambah pengetahuan kosa kata peserta didik, biasanya setiap malam setelah shalat isya berjama'ah peserta didik akan diberi beberapa kosa kata baru setiap malamnya oleh pengurus organisasi santri.

5. Ziarah kubur

Sebagai bentuk hormat dan kecintaan peserta didik kepada Kyai Ahmad Shonhaji Cholili sebagai pimpinan pertama yayasan, setiap peserta didik mendapat giliran untuk ziarah ke makam kyai Shonhaji sesuai dengan pembagian yang telah ditentukan.

6. Pengajian kitab kuning

Untuk menunjang pembentukan karakter islami pada peserta didik, dilangsungkannya pengajian kitab kuning bersama ustadz maupun ustadzah yang berangsung dengan cara membuat lingkaran kecil atau halaqah maupun dikelasnya masing-masing. Adapun pelaksanaan ngaji kitab kuning ini berlangsung setelah shalat shubuh berjama'ah sampai pukul 05:45 WIB. Kitab-kitab kuning tersebut meliputi Safinatun 
Najjah, Fathul Qarib, Fathul Mu'in, Riyadhul Badiah, Talimul Tal'lim.

7. Piket kebersihan

Dalam membentuk karakter cinta lingkungan, pembiasaan yang dilakukan adalah dengan kegiatan piket kebersihan. Kegiatan kebersihan ini dilangsungkan pada ruang kelas, masjid, kamar dan lingkungan pondok lainnya.

\section{c. Keteladanan}

Upaya selanjutnya yang paling efektif yaitu dengan keteladanan. Keteladanan adalah suatu hal yang dapat ditiru atau contoh. Keteladanan di pesantren diperankan oleh kyai, kepala sekolah, guru, pengurus dan tenaga kependidikan yang ada di pesantren. Pribadi guru memiliki andil yang sangat besar terhadap keberhasila pendidikan, terutama dalam pembentukan karakter. Hal ini didasari karena manusia merupakan makhluk yang suka mencontoh.

Sebagaimana dengan ungkapan Ahmad Haromaini dalam jurnalnya yang berjudul "Mengajar dengan Kasih Sayang" dikatakan bahwa seorang guru tidak hanya menjadi teladan bagi peserta didiknya, tetapi ia juga berperan sebagai pengendali dan pengarah peserta didik pada sebuah proses membentuk manusia yang lebih baik lagi. ${ }^{13}$

Dengan adanya keteladanan yang ditunjukkan kepada peserta didik, memudahkan pesantren dalam proses pembetukan karakter islami. Sebab peserta didik lebih mudah untuk meniru apa yang dilakukan gurunya ketimbang mengerjakan apa yang diperintahkan gurunya.

\section{d. Teguran dan nasihat}

Seorang guru perlu menegur peserta didik yang melakukan kesalahan, hal itu bertujuan untuk mengingatkan peserta didik agar tidak melakukan hal yang dilarang atau keliru. Setelah memberikan teguran, tidak lupa pula pemberian nasihat. Nasihat yang terus diulang-ulang baik yang berupa sebagai penyejuk hati maupun untuk menegur kebiasaan yang tidak sesuai dengan syariat terus dilakukan untuk mengingatkan anak didik.

\section{e. Hadiah dan hukuman}

Pemberian hadiah dan hukuman yang seimbang kepada peserta didik merupakan upaya yang dijadikan sebagai perantara menuju kepada proses menumbuhkan motivasi. Hadiah yang sudah dilakukan tidak harus berupa barang yang mahal, cukup dengan pujian atau kata-kata yang

${ }^{13}$ Ahmad Haromaini, 'Mengajar Dengan Kasih Sayang' Rausyan Fikr. Vol. 15 No. 2 September (2019). 
dapat membesarkan hati peserta didik, begitu juga hukuman yang telah diterapkan tidak harus dengan sesuatu yang berat seperti mengambil sampah, menulis ayat $\mathrm{Al}-\mathrm{Qur}$ 'an dan sebagainya. Hadiah dan hukuman cukup sebagai perantara peserta didik agar termotivasi dalam melaksanakan pembiasaan yang baik tetap berkelanjutan.

Pemberian hukuman ini tidak hanya sekedar memberikan hukuman kepada peserta didik. Sebagaimana hasil dari observasi yang penulis lakukan di lokasi penelitian, diketahui bahwa hukuman-hukuman yang diberikan pada peserta didik merupakan hukuman yang sudah disepakati oleh pengurus dengan peserta didik dan disetujui oleh pesantren.

jika dalam teori pembentukan karakter kita mengenal trilogi pembentukan karakter seperti yang diungkapkan oleh Thomas Lickona, yakni konsep moral (moral knowing), sikap moral (moral feeling), dan perilaku moral (moral behavior), ${ }^{14}$ maka Pesantren Modern Daarul Muttaqien 11 Pasar Kemis ini dapat dikatakan mempraktikkan ketiga trilogi itu dalam proses pendidikan mereka.

Moral knowing dan moral feeling mereka lakukan dalam proses pendidikan dan pembelajaran,

${ }^{14}$ Marzuki, Pendidikan Karakter...., h. 21 sementara moral behavior mereka praktikkan dalam kehidupan sehari-hari melalui intervensi kegiatan-kegiatan yang terjadwal dan terencana secara ketat mulai bangun tidur di pagi hari hingga tidur kembali di malam hari, intervensi kegiatan-kegiatan peserta didik dilakukan agar para peserta didik dapat melakukan kegiatan-kegiatan itu secara berulang-ulang sehingga terbiasa untuk berperilaku baik.

Pendapat Lickona tentang pembentukan karakter di atas kemudian diperkuat oleh Ryan dan Bohlin dengan mengatakan bahwa pendidikan karakter sebagai proses: knowing the good, loving the good, dan doing the good. ${ }^{15}$ jika pendapat Ryan dan Bohlin ini digunakan untuk melihat proses pembentukan karakter di pesantren, maka ketiga proses itu terlihat dalam keseluruhan proses pendidikan yang berlangsung di pesantren selama 24 jam, yang oleh kalangan pesantren dikatakan sebagai total quality control, agar lahir generasi muslim yang berkarakter islami.

Pengenalan tentang apa yang baik dan yang buruk serta cinta kepada kebaikan dilakukan pesantren dalam pembelajaran forma, ada materi-materi ajar yang dapat disebut di sini sebagai proses pengenalan tentang kebaikan dan

\footnotetext{
${ }^{15}$ Marzuki, Pendidikan Karakter..., h. 22
} 
cinta kepada kebaikan. Mata pelajaran Mahfudzat misalnya mengajarkan tentang kesabaran, kesungguhan, kejujuran yang bermanfaat bagi kemanusiaan. Ungkapan-ungkapan ringkas dan padat yang terkandung dalam pelajaran Mahfudzat inilah yang diajarkan kepada peserta didik, kemudian mereka mencerna dan rasakan, dan akhirnya mereka lakukan dalam kehidupan sehari-hari.

Merujuk pada gambaran pelaksanaan pendidikan karakter yang dikembangkan oleh Kemendiknas, Pondok Pesantren Modern Daarul Muttaqien II Pasar Kemis tampak telah lama melakukan tahap-tahap itu. Bahkan pembentukan karakter islami atau pendidikan karakter dalam proses pembelajaran dilakukan secara integral dalam semua mata pelajaran. Begitu juga pendidikan karakter dalam kegiatan keseharian dalam bentuk budaya sekolah.

Di Pondok Pesantren Modern Daarul Muttaqien 11 Pasar Kemis, budaya pesantren telah tercipta sejak pesantren tersebut didirikan hingga sekarang, budaya ikhlas, sederhana, berdikari ukhwah Islamiyah, dan kebebasan merupakan budaya yang telah ditransformasikan secara turun temurun dalam lingkungan pesantren. Budaya pesantren juga dibentuk melalui proses intervensi berupa kegiatankegiatan harian, mingguan, bulanan dan tahunan yang dilakukan untuk membiasakan santri sehingga terbentuk sebuah budaya khas yang berbeda dari budaya-budaya sekolah yang ada di luar pesantren.

Dan keunggulan pesantren dalam pembentukan karakter islami terletak pada sistem asramanya yang memungkinkan pesantren untuk menerapkan pembelajaran intrakulikuler dan ekstrakulikuler bagi semua warga pesantren. Organisasi santri yang mengorganisir seluruh kegiatan santri ditambah dengan kegiatan-kegiatan lainnyayang sengaja dibuat memungkinkan terbentuknya karakter kemandirian, religius, kepedulian yang kuat baik kepada lingkungan atau sosial, tanggung jawab, kejujuran komunikatif, kerja keras, kreatif, dan kedisiplinan.

lingkungan pesantren dapat disebut sebagai lingkungan masyarakat yang memiliki nilai, tradisi, dan norma yang selalu menggiring peserta didik untuk melakukan perbuatan-perbuatan baik, sebab jika ada warga pesantren yang melanggar nilai- tradisi, maupun norma pesantren, maka sangsi akan segera dikenakan kepada peserta didik tersebut. Karena dapat dikatakan pesantren merupakan institusi pendidikan yang secara total 
menerapkan pendidikan karakter dalam setiap aktivitas pendidikan dan pembelajarannya.

\section{KESIMPULAN}

Berdasarkan hasil penelitian dan pembahasan di atas, dapat ditarik kesimpulan bahwa dengan mengintegrasikan nilai-nilai karakter islami pada semua mata pelajaran (intrakulikuler), mengintegrasikan nilainilai karakter islami diluar kelas (ekstrakulikuler) dengan cara keteladanan, pembiasaan, pemberian teguran dan nasihat serta pemberian hadiah dan hukuman.

\section{DAFTAR PUSTAKA}

Anwari, Ahmad Mufid, 2020. Potret Pendidikan Karakter di Pesantren: Aplikasi Model Keteladanan dan Pembiasaan dalam Ruang Publik, Tasikmalaya: Edu Publisher,.

Hanafi, Halid et.al., 2019. cet. ke-2, Ilmu Pendidikan Islam, Yogyakarta: Deepublish,.

Haromaini, Ahmad, 'Mengajar Dengan Kasih Sayang' Rausyan Fikr. Vol. 15 No. 2 September (2019).

Holisoh, Ade Karmawan, dan Nur Halimah, Kedisiplinan Siswa Dan Motivasi Belajar Dalam
Meningkatkan Prestasi Belajar Siswa Pada Pelajaran Akuntansi Di Madrasah Aliyah Negeri Kabupaten Tangerang, 14.1 (2020), 80.

https://kbbi.kemdikbud.go.id/entri/islami, diakses pada hari Senin tanggal 14 Juni 2021 pukul 13:35 WIB,.

Marzuki, 2015. cet. ke-l, Pendidikan Karakter Islam, Jakarta: Bumi Medika,.

Noviaturrahmah, Fifi, 'Metode Pendidikan Karakter di Pesantren', Jurnal Pendidikan Agama Islam, 11.2 (2017), 20116.

Nugraha, Mohammad Fahmi, et.al., 2020. cet. ke-1, Pengantar Pendidikan dan Pembelajaran di Sekolah Dasar, Tasikmalaya: Edu Publisher,.

Pusat Bahasa Departemen Pendidikan Nasional, 2008. Kamus Bahasa Indonesia, Jakarta: Pusat Bahasa,.

Ramayulis, 2008. Ilmu Pendidikan Islam, Jakarta: Kalam Mulia,.

Wahyuningtyas, Indah, 'Upaya Pembentukan Karakter Islami Siswa', Journal of Chemical Information and Modeling, 53.9 (2019), 1689-99. 
Yaumi, Muhammad, 2016. cet. ke-2,

$\begin{array}{lr}\text { Pendidikan } & \text { Karakter: } \\ \text { Landasan, Pilar, } & \text { dan } \\ \text { Implementasi, } & \text { Jakarta: }\end{array}$

Kencana,.

Yuliharti, 'Pembentukan Karakter Islami dalam Hadis dan Implikasinya pada Jalur Pendidikan Non Formal', Potensia: Jurnal Kependidikan Islam, 4.2 (2019). 
(Halaman sengaja dikosongkan) 